\title{
An Empirical Study of Factors Related to Consumer Complaint Behavior
}

\author{
Meilian Liu ', Feng Zhang ${ }^{2}$ \\ 1 Management College, Guilin University of Electronics and Technology, \\ Guilin Guangxi, P.R. China 541004 \\ merryjanes@126.com \\ 2 Management College, Guilin University of Electronics and Technology, \\ Guilin Guangxi, P.R. China 541004, \\ mlliu@guet.edu.cn
}

\begin{abstract}
This paper focuses on factors related to consumer complaint behavior tendency in Internet. Current literatures from home and abroad focus on how to improve consumer's satisfaction and loyalty, while there are still relatively few researches on consumer dissatisfaction and complaint behavior. Based on the analysis of consumer complaint behavior tendency in Internet, this paper discusses the factors related to consumer complaint behavior. Hypothesis test of the factors by means of structural equation model, and the model has been modified by LISREL software and has come a conclusion that some factors are related to consumer complaint behavior in Internet. The research indicates that the factors, which consist of online consumer characteristics, product characteristics, consumer attitude to complaint, customer satisfaction and shopping experience, have a positive impact on web consumer complaint behavior tendency.
\end{abstract}

\section{Introduction}

As early as the 1970 s, the business managers and scholars have taken concerns to consumer complaint problem. With the development of E-commerce, researches on customer behavior, especially customer satisfaction and complaint behavior have appeared gradually. How to solve the consumer complaint problem properly is an effective "defensive marketing" strategy, which contributes to remain the existent customers and obtain new customers.

According to Shop.org and Forrester Study, U.S. network retail sales in 2006 will reach 211 billion increased by $20 \%$ compared to 2005 . With rapid development of online retail sales, online shopping is more and more popular. However, because of open system, it is very difficult for enterprises to completely reach "zero defects". When the actual services are inconsistent with the expected service, consumers will be dissatisfied. In this case, they may choose to complain, remain silent but turn to competitors or remain silent and continue to purchase. To get valuable information about customer complaint, enterprises can realize the real need of consumers and identify the existing problems of products and services, and then persist in improving service. Therefore, to research consumer complaints and the related factors are very necessary to improve network enterprise products and services. Effective 
management of customer complaints enterprises can obtain at least the following advantages. Firstly, to manage consumer complaints can be used for strategic planning and operations. Secondly, it contributes to a targeted marketing activity. Thirdly, customer satisfaction and brand loyalty can be improved.

\section{Related Work Review}

Researches related to consumer complaints began in the early 1970 s, which were affected by the consumer conciliarism. Early studies focused on describing general consumer characteristics in different industries and summarizing complaint characteristics and methods. These researches often concentrate on such fields: The actions customers may take and the factors related to unsatisfied situation; the reasons for consumer complaints and the cost of consumer complaints.

From the end of 1970 s to the beginning of 1990 s, scholars began to seek for building theories and models which can explain and predict complaint behavior. Most studies focused on the following three aspects: Firstly, it was to research whether complains were related to industry competition; Secondly, whether complaints were related to consumers' perceptions to service providers or not. Thirdly, it was to analyze whether complaint intentions were related to consumer attitudes to complaints or not. By means of the gathered data from three service industries, Singh analyzed the interrelationship between customer attitudes to complaints, dissatisfaction and complaining intentions [1]. Lastly, the researches studied other factors which had an impact on complaints $1[2,3,4]$.

After the 1990s, researches on consumer complaints developed rapidly. Plymire concluded that the complaint-generation process results in a customer focused culture in which complaints are regarded as an opportunity [5]. Hansen analyzed consumer's response to the unsatisfied state and suggested that to deal with complaints properly should help prevent consumer from loss [6].

Studies from foreign countries on consumer complaining behavior such as American have gradually become mature, which focus on two areas primarily. In view of research fields, they focused on whether, when, why, how to complain and how to deal with complaints, and they put emphasis on varied methods, such as empirical research, model prediction and so on. In view of research objects, there exist both characteristics of consumer complaint studies from consumers and the importance of marketing management from enterprises perspective [711].

At present, the research on consumer complaints in China is still at the initial stage. Most scholars confined to the complain superficies without deeper investigation, so there were not complete and mature theories; In business domain, owing to the lack of theories guide and special cultural backgrounds, there is no enough attention though many consumer complaints exists in practical e-marketing.

Ping Zhao investigated five durables businesses by questionnaire and researched the factors related to consumer complaint which are general characteristics of Chinese consumer complaint, differences in demographic characteristics and characteristics of product itself [12]. Xiucheng Fan researched such factors of procession system for consumer complaint as the collection and analysis of complaint information, organization learning 
mechanism and its continuous improvement and authorization [13]. He also discussed the effect that value orientation imposed on consumer complaint. According to value orientation, consumers were divided into three groups: disadvantaged groups, individualism consumers and strong pressure consumers. The research showed that the factors related to complaint behavior are different for consumers in the same state with different value orientation [14].

\section{Analysis of the Reason for Internet Consumer Complaint and Characteristics}

\subsection{Reason for Web Consumer Complaint}

Why web consumers complain is just from their dissatisfaction with the provided products and services. Two main reasons for their dissatisfaction are product problem and service problem as well as the limitations from the Web consumer capability of their cognition products and services. It is often that consumers complain because of product problem, for example, the delivered product is not the same as the ordered, the products are damaged, and the inferiority products are regarded as superiorities. The service problems appear as such forms as: too late delivery, too many network advertisements, the complicated log process in Internet and unsafe online payments.

\subsection{Complaint Type of Web Consumers}

According to different complaint path, the complaint types of Web consumers can be divided into three types: direct complaint, private complaint and third party complaint.

Direct complaint refers to the Web consumers make complaints to the suppliers or service providers related to the specified transaction. Private complaint is Web consumers complain to his groups who are irrelative to the given bargain. For example, one has purchased some product in Internet, the consumer will complain to his groups by Email, bulletin board and other communication method

Contrast with the former two, third party complaint refers to Web consumers complain to objects who don't belong to his groups and are not related to the product or service providers in a transaction

\subsection{Cobsumer Complaint Characteristics}

Compared with consumer complaint behavior in the traditional commerce, Web consumer complaint behavior shows some new characteristics:

$>$ Network is a main complaint channel. Because of network convenience, fast information spread and extensive spread area, Web consumers will make complaints to the purchased product and service by means of supplier service platform, BBS and QQ chat room to abreact their dissatisfaction and search for a proper solution.

$>$ Complaint mode is diversified, but direct complaint is preferred. Web consumers pay more attention to individuation and their wish 
realization compared with the consumers in traditional commerce. Once the purchased products or services are far away from their expectation, they will be dissatisfied and tend to abreact dissatisfaction by direct complaint manner.

$>$ The factors related to consumer behavior are more complicated. Because of the virtual network, risky online payment and laggard distribution system compared with traditional commerce, the latent factors related to consumer dissatisfaction and consumer complaints are more complicated [15].

\section{Empirical Research on the Factors Related to Complaint Behavior of Web Consumer}

\subsection{Method}

Structural Equation Modeling is a multi-statistical analysis technology which integrates the regression analysis with factor analysis method together properly [16]. Besides estimating the factorial structure and relationship, SEM doesn't have strict limitations, so it can cope with many observable variables and potential variables, and provides possibility to analyze the structure relationship of potential variables ${ }^{[17]}$. Because web consumers complaint behavior is very complicated, to adopt traditional method such as regression analysis is not ideal, regression analysis must suppose the observation variable don't have error, while SEM allows the statistical relationship of observation variables to provide regression estimation coefficient of potential variables, so it provides opportunity from statistics supposition to confirm factors related to web consumer behavior.

\subsection{Factor Supposition Related to Web Consumer Complaint Behavior}

The Web consumer will inevitably encounter dissatisfied in web shopping and complaints appear. When web consumer are dissatisfied, they may propose complaints, keep silence but turn to competitor, keep silence and continue to purchase and so on. However, only to understand factor related to web consumer complaint behavior can enterprise cope with the complaint behavior effectively, and turn web consumer from dissatisfaction to satisfaction.

Hypothesis 1: Web consumer complaint attitude is related to complaint tendency

Web consumer complaint attitude will have impact on whether consumers resort to actual complaint behavior or not. The Web consumer complaint behavior could be divided into three dimensionalities: (1) whether complaint is worth? (2) Individual standard of complaint behavior. (3) The possibility of profit by complaint. The complaint tendency is relative to how serious the problem is which the web consumer perceived, the offered price, complaint cost and so on. If to complaint needs more cost than benefits, they choose not to complain. If complaint needs the specific knowledge of related service as well as the communication skill, but the consumer lack for these abilities and knowledge, then the consumer will not complain. When the Web consumer sense the 
enterprise will process the complaint properly, and will provide remedial treatment to not perfect product and service, they tend to complain. Here we discussed complaint manner from the three aspects of complaint cost, the skill and the complaint income.

Hypothesis 2: the individual characteristic of Web consumer is related to complaint tendency.

The young people have greater desire to express their desirability, and the web consumers who have higher educational background may have specific product and service knowledge as well as communication skill. From the viewpoint of sex, there are big differences at proposing their own opinions boldly and powerfully or claiming themselves' right between male and female. The male generally express their anger more calm than the female in the public situation. And when they are unsatisfied, the male has intense tendency to adopt complaint. Bearden's research discovered that, the race, the employment condition and the family type for the influence of the complaint behavior of consumer is not remarkable.

Hypothesis 3: Web product characteristic is related to complaint tendency.

The product type, price, quality, complexity and expected life-span of the network product, besides how serious the problem is which arose from product and service and so on both have influence to the consumers' complaint behavior. Regarding to the research of electric appliance, Bradford found the type, the price and the life expectancy of product is related to consumer's complaint behavior too ${ }^{[18]}$. When faced with problems from commodity with low price, the consumer generally don't complain directly, but will turn to the competitor next time because of lower switch cost. But for durable commodity with high price, the consumer prefers to direct complaint if he is dissatisfied to expect gains from the solved dissatisfaction problem by complaint. As for characteristic of the network product, we choose the produce or service price, expected life-span of the network product, the competition advantage of industry which the product belongs to are related to corporation image and complaint tendency. Generally speaking, the quality is included in the price, and web consumers think it necessary for corporations to maintain their image, good enterprise will attach more importance to the complaint problem thus the web consumers tend to complain. When web consumers are dissatisfied, whether the web consumers propose complaint or not is related to how intense the product competition among industries is. On condition that a greater number of competitors exist, as switch cost is low, the consumers tend not to complain, possibly remain silence but change to the competitor. Next, complaint is related to the consumer cognition of how to cope with complaint which is provided by the suppliers. If the consumers felt the enterprise can make positive response to service defaults, and can take care of consumers' complaint, then, the probability of consumer complaint is bigger [19].

.Hypothesis4: the Web consumer's satisfaction is related to complaint tendency.

Since complaint is from the Web consumer's dissatisfaction, then the relation between network satisfaction and complaint tendency is negative obviously. However, when loyal consumers for some certain brand or enterprise are dissatisfied, as long as they are not very unsatisfied, they will keep silence and continue to patronage. This paper will make a discussion between web consumer satisfaction and the complaint behavior tendency.

Hypothesis 5: On-line shopping experience is related to complaint tendency. 
For consumers who experienced on-line shopping first time, when they are dissatisfied with on-line shopping, they may lose confidence in the electronic commerce, and give up online shopping; certainly they choose not to make complaint to online stores. Otherwise, they change shopping websites frequently. But for the consumer who always navigates in the shopping website, when they are dissatisfied with on-line shopping, they tend to complain to on-line store. Moreover, for those who like to chat online frequently, and web consumers possibly tend to complain in private to share their unsatisfied shopping experience with their good friends and other netizens.

Hypothesis 6: Web consumer individuality characteristic is related to Web consumer's complaint behavior tendency of Web consumer complaint manner.

Each web consumer has his individual characteristic, according to theory of planned behavior, different Web consumer shows different complaint manner ${ }^{[20]}$ [21]. Therefore, we suppose that web consumer's individuality characteristic is related to Web consumer's manner to complaint, and even does have effect on web consumer's complaint tendency.

Based on the hypothesis what discussed above, we established the factor model of the web consumer complaint tendency, as show in fig. 1 .



Fig.1. A conceptual model of Web consumer complaint behavior

\subsection{Data Acquisition}

This paper mainly focused on the customers who have experience in internet shopping by questionnaire. Most of the questionnaires have been sent out in Internet accompanied by paper questionnaire. We randomly selected 160 people, but because of incomplete and wrong information, only 152 people's questionnaires are valid. The valid rate is $95 \%$. The average age of the people is 30 years old, $40 \%$ of which is female. From education situation, we can see that the rate of people with senior high school education background is $32 \%$, while the proportion of college background is $25 \%$. Population with college and even higher education background is $31 \%$. From the view of occupation, students have a big rate is $36 \%$. This result is accorded with the statistics report of CNNIC; there is no significant difference between them. 


\subsection{Variables in the Model}

Six variables are involved in this model which are characteristics of internet customer, products characteristics, the attitudes of internet customer to complain, the satisfaction of internet customer, the internet shopping experience and incline of complain.

Table 1. Potential variables and number of index

\begin{tabular}{l|l}
\hline Potential Variable Element & \multicolumn{1}{c}{ Index } \\
\hline characteristics of internet customer & 4(age, sex, education, governable income) \\
\hline products characteristics & $\begin{array}{l}\text { 4(price, expectable used time, product image, } \\
\text { characteristic of industry) }\end{array}$ \\
\hline $\begin{array}{l}\text { attitudes of internet customer to } \\
\text { complain }\end{array}$ & 3(cost, technician, profit) \\
\hline Internet customer satisfaction & $\begin{array}{l}\text { 3(quality of product purchased, delivery } \\
\text { time, payment safety) }\end{array}$ \\
\hline Internet shopping experience & 3(time, quantity, frequency) \\
\hline Complaint tendency & $\begin{array}{l}\text { 3(possibility of complain, reasonable of } \\
\text { complain, change of supplier) }\end{array}$ \\
\hline
\end{tabular}

All these potential variables are included in 21 questions. The sample is analyzed by EFA by Lisrel 8.53 . The main indexes used in research of complaint have been tested successfully by credibility analysis. The main variables are shown in the Table 1.

\subsection{Test Result}

In this research, we have tested Web consumer complaint tendency model by SEM. And we have established the structural model by Lisrel 8.53 software. The reliability coefficient for characteristics of Web customer, products characteristics, attitudes of Web customer to complain, Web customer satisfaction and Internet shopping experience is respectively $0.75,0.79,0.86$, 0.88 and 0.71 respectively. It shows that the questionnaire has good credibility.

Table 2. Loadings and error of apparent variable on potential variable

\begin{tabular}{c|c|c}
\hline Supposed Description & Loading & Error \\
\hline Web customer age $\rightarrow$ Characteristic & 0.6 & 0.82 \\
\hline $\begin{array}{c}\text { Sex of Internet customer } \rightarrow \text { characteristics } \\
\text { customer } \rightarrow \text { Characteristics }\end{array}$ & 0.6 & 0.66 \\
\hline $\begin{array}{c}\text { Controllable income } \rightarrow \text { Characteristics } \\
\text { Low value Products } \rightarrow \text { Characteristic of } \\
\text { Internet Products }\end{array}$ & 0.58 & 0.52 \\
\hline $\begin{array}{c}\text { Internet Products } \\
\text { High value Products } \rightarrow \text { Characteristic of } \\
\text { Inter }\end{array}$ & 0.45 & 0.84 \\
\hline $\begin{array}{c}\text { Expected product life } \rightarrow \text { Characteristic of } \\
\text { Internet Products }\end{array}$ & 0.87 & 0.82 \\
\hline $\begin{array}{c}\text { Product Image } \rightarrow \text { Characteristics of Internet } \\
\text { Products }\end{array}$ & 0.66 & 0.62 \\
\hline
\end{tabular}




\begin{tabular}{|c|c|c|}
\hline $\begin{array}{l}\text { Industry Characteristic of Products } \rightarrow \\
\text { Characteristic of Internet Product }\end{array}$ & 0.71 & 0.78 \\
\hline $\begin{array}{c}\text { Complain Cost } \rightarrow \text { attitudes to web consumer } \\
\text { complaint }\end{array}$ & 0.80 & 0.54 \\
\hline $\begin{array}{l}\text { Benefit of Complaint } \rightarrow \text { attitudes to web } \\
\text { consumer complaint }\end{array}$ & 0.62 & 0.34 \\
\hline $\begin{array}{l}\text { Skills of Complain } \rightarrow \text { attitudes to web } \\
\text { consumer complaint }\end{array}$ & 0.66 & 0.52 \\
\hline Quality of Product purchased $\rightarrow$ Satisfaction & 0.64 & 0.48 \\
\hline $\begin{array}{c}\text { Delivery Time of Product } \rightarrow \text { Satisfaction } \\
\text { Content }\end{array}$ & 0.54 & 0.44 \\
\hline Safety of Payment online $\rightarrow$ Satisfaction & 0.76 & 0.57 \\
\hline $\begin{array}{l}\text { Time of Starting Internet shopping } \rightarrow \\
\text { Experience of Internet Shopping }\end{array}$ & 0.52 & 0.65 \\
\hline $\begin{array}{l}\text { Frequency of Internet Shopping } \rightarrow \\
\text { Experience of Internet Shopping }\end{array}$ & 0.36 & 0.72 \\
\hline $\begin{array}{l}\text { Times of Internet Shopping } \rightarrow \text { Experience of } \\
\text { Internet Shopping }\end{array}$ & 0.75 & 0.7 \\
\hline $\begin{array}{c}\text { Possibility of Complaint } \rightarrow \text { Complaint } \\
\text { tendency }\end{array}$ & 0.79 & 0.46 \\
\hline $\begin{array}{c}\text { Perceived sensibility of } \\
\text { Complaint } \rightarrow \text { Complaint tendency }\end{array}$ & 0.55 & 0.7 \\
\hline Supplier switch cost $\rightarrow$ Complaint tendency & 0.86 & 0.44 \\
\hline
\end{tabular}

In order to verify whether the suppositions are correct or not, the results are shown in table 2 and table 3 by factor analysis and path analysis. According to the supposed model, we can see that every path significance is 0.05 . In this research, we choose to report 5 fit indexes to explain the model, which are $\mathrm{X}^{2}$, NNPI, CFI, GFI, RMSEA. These parameters provide different meanings of the supposed model from different aspects. Generally speaking, if the NNPI and CFI are both above 0.9 , the models have better fit. If the RMSEA is below 0.1 , the model can be accepted based on the gathered data.

Table 3. Related Index Comparison of Nested Model and Supposed Model

\begin{tabular}{cccccccr}
\hline Model & $\mathrm{X}^{2}$ & df & NNFI & CFI & GFI & RMSEA & $\triangle \mathrm{X}^{2}(\triangle \mathrm{df})$ \\
Supposed Model & 146.42 & 94 & 0.96 & 0.97 & 0.89 & 0.04 & \\
Nested Model 1 & 151.51 & 95 & 0.95 & 0.97 & 0.90 & 0.04 & $5.09(1)$ \\
Nested Model 2 & 152.45 & 95 & 0.95 & 0.97 & 0.90 & 0.04 & $6.03(1)$ \\
Nested Model 3 & 162.34 & 95 & 0.94 & 0.97 & 0.89 & 0.05 & $15.92(1)$ \\
Nested Model 4 & 165.56 & 95 & 0.96 & 0.97 & 0.90 & 0.06 & $19.14(1)$ \\
Nested Model 5 & 172.35 & 95 & 0.96 & 0.97 & 0.90 & 0.06 & $25.93(1)$ \\
Nested Model 6 & 151.58 & 95 & 0.95 & 0.97 & 0.90 & 0.05 & $5.16(1)$ \\
Nested Model 7 & 150.51 & 95 & 0.94 & 0.95 & 0.90 & 0.04 & $4.09(1)$ \\
Nested Model 8 & 176.65 & 96 & 0.96 & 0.97 & 0.90 & 0.04 & $30.23(2)$ \\
\hline
\end{tabular}

Note:

Nested model 1: Based on the supposed model, the path from characteristic of Web customer to consumer complaint behavior tendency is deleted directly.

Nested model 2: Based on the supposed model, the path from characteristic of Web products to consumer complaint behavior tendency is deleted directly.

Nested model 3: Based on the supposed model, the path from attitude of Web customer to consumer complaint behavior tendency is deleted directly. 
Nested model 4: Based on the supposed model, the path from characteristic of Web products to consumer complaint behavior is deleted directly.

Nested model 5: Based on the supposed model, the path from satisfaction of Web customer to consumer complaint behavior is deleted directly.

Nested model 6: Based on the supposed model, the path from experience of Web shopping to consumer complaint behavior is deleted directly.

Nested model 7: Based on the supposed model, the path from characteristic of Web customer to consumer complaint behavior is deleted directly.

Nested model 8: Based on the supposed model, the path from characteristic of Web customer to consumer complaint behavior is deleted directly and the path from attitude of web customer to consumer complaint behavior is also deleted directly.

According to results of table 3 , it can be proved that the supposed model is appropriate. Except for the nested model 7, the other nested models are statistically correct. We suppose these potential variables have effect on complaint behavior tendency independently. The nested model will be inappropriate no matter any path is deleted. Therefore, the rest six suppositions we have established are proved to be true. Therefore, the result of path analysis is shown in the fig.2.

\section{Conclusion and Remarks}

A structural model has been established which consists of key factors related to web customer behavior, and we can come to such conclusion:



Fig.2. The factors related to web consumer complaint behavior tendency

Individual diversity of web customers. Many factors are related to web consumer complaint tendency such as sex, age, education background, controllable income and independence. Contrast with the people who have higher education background and more controllable income tend to complain, the young prefer complaint to the aged.

$>$ Complaint attitude is related to complaint tendency. The complain attitude of web customers can be measured by three indexes: 1) complaint cost; 2) whether complaint requires special skills; 3) 
perceived increased income for complaint consumer. A more intensive attitude may cause complaint tendency.

$>$ Satisfaction and complain is related to complaint behavior tendency negatively. Customers are more inclined to complain directly if they are more dissatisfied but they keep silence or switch to the competitors.

Characteristic of web products is related to complaint tendency. The more complicated is the product, the more the consumer will tend to complain. However, some related factors have been ignored such as web advertisement, value orientation, Web consumer perception and so on. What's more, how complaint come into being based on given spatial and temporal factors and environment must be further researched.

\section{Reference}

1. Singh, J. and R.E.Wilkes., "When Consumer Complain: A Path Analysis of Consumer Complaint Response Estimated" [J]. Journal of the Academy of Marketing Science, 1996, 24(4), pp.350-365.

2. Singh Jagdip. "Exit, Voice, and Negative Word-of-mouth Behaviors: An investigation across three service Categories" [J]. Journal of the Academy of Marketing Science, Winter, 1990(18), pp.1-15.

3. Beard WO, Teel J E. "Selected determinants of consumer satisfaction and complaint reports" [J]. Journal of Marketing Research, 1983(20), pp.21-28.

4. Fornell,Claes and BIrger Wernerfelt. "Defensive Marketing Strategy by Customer Complaint Management: A Theoretical Analysis" [J]. Journal of Marketing Research, 24(November), 1987, pp.337-346.

5. Plymire, J. "Complaints as Opportunities". [J].Journal of Consumer Marketing, Vol. 8, 1991, pp.39-43.

6. Hansen, Scott W., Thomas L. "Powers and John E. Swan. Modeling Industrial Buyer Complaints: Implication for Satisfying and Saving Customers" [J].Journal of Marketing, 1997, pp.12-22

7. Sridhar Balasubramanian,Prabhudev Konana,Nirup M. Menon, "Customer Satisfaction inVirtual Environments: A Study of Online Investing"[J]. Management Science, 2003, Vol.49, Issue 7.

8. Isabelle Prim, Bernard Pras," "friendly" complaining behaviors: toward a relational approach" [J].Journal of Market-Focused Management, 1999, vol.3, pp.333-352.

9. Mustafa Jarrar, Ruben Verlinden, Robert Meersman, "Ontology-Based Customer Complaint Management" [J]. Lecture Notes in Computer Science, vol.2889/2003, pp.594-606.

10. McAlister, Debbie Thorne. "A content analysis of outcomes and responsibilities for consumer complaints to third-party organizations"[J]. Journal of Business Research, 200356 (4), pp.341-351.

11. Y.Cho,I. Im,R. Hiltz,J. Fjermestad, An Analysis of Online Customer Complaints: Implications for Web Complaint Management[C].Proceedings of the 35th Annual Hawaii International Conference on System Sciences (HICSS'02) Volume 7,2002.

12. P. Zhao, Y.L Mo."Study on Consumer complaint Behavior in Durable Goods in China"[J].Journal of Tsinghua university, 2002,(2). 
13. X.C Fan. "Consumer Complaint Management System of Service Corporation Oriented to Consumer Satisfaction"[J].Chinese Journal of Circulation Economy, 2002 (2), pp.40-44.

14. X.C Fan. "Value Oriented is Related to Consumer Complaint Tendency"[J].Nankai Management Review, 2002,(5), pp.11-16.

15. Z.C Li, M.L Liu. "Consumer Behavior Study in Electronic Commerce"[J] Chinese Journal of management science, 2002, 10(6), pp. 88-91.

16. Y. Shen, P. Zhao. "BB Model and Empirical Bayes Method Used in Complaint Behavior Tendency" [J].Journal of Statistics Research. 2004(11), pp.55-59.

17. J.T Hou .Structural Equation model and Its Applications [M].Beijing: Educational Science Publishing Science, 2004.

18. Bradford, Adelina Broadbridge, Julie Marshall. "Consumer Complaint Behavior: The case of electrical goods"[J].International Journal of Retail \& Distribution Management, 1995, VOI 23, issue 9, pp.8-18.

19. Christy M. K.Cheung, Matthew K.O. Lee, Consumer satisfaction with internet shopping: a research framework and propositions for future research[C]. Proceedings of the 7th international conference on Electronic commerce 2005. 20. Y.G Wang, Hing-Po Lo, Y.H Yang, "An Integrated Frameworkfor Service Quality, Customer Value, Satisfaction: Evidence from China's Telecommunication Industry"[J]. Information Systems Frontiers, vol.6/2004,issue.4.

21. Terry L. Childersa, ${ }^{*}$, Christopher L. Carrb, Joann Peckc, Stephen Carsond. "Hedonic and utilitarian motivations for online retail shopping behavior" [J]. Journal of Retailing, 77 (2001), pp.511-535. 